\title{
Verification of ET and Al Derived Offspring Using on the Genetic Polymorphisms of Microsatellite and Coat Color Related Genes in Jeju Black Cattle
}

\author{
Sang-Hyun Han, Jin-Cheul Ko', Young-Hoon Kim', Kim Nam-Young, Kim Jae-Hwan, Moon-Suck Ko, \\ $\mathrm{Ha}-$ Yeon Jeong, In-Cheol $\mathrm{Cho}^{2}$, Young-Hoon Yang ${ }^{3}$ and Sung-Soo Lee*
}

\author{
Subtropical Animal Experiment Station, National Institute of Animal Science, RDA, Jju 690-150, Korea \\ ${ }^{1}$ Institute for Livestock Promotion, Jeju Special Self-governing Province, Jeju 690-802, Korea \\ ${ }^{2}$ Animal Genomics \& Bioinformatics Division, National Institute of Animal Science, RDA, Suwon 441-706, Korea \\ ${ }^{3}$ Department of Animal Biotechnology, Jeju National University, Jeju 690-756, Korea
}

Received December 3, 2009 / Accepted January 14, 2010

\begin{abstract}
To find offspring of Jeju Black cattle (JBC) produced by embryo transfer (ET) and artificial insemination (AI), a molecular genetic study was carried out in candidate cattle populations collected from cattle farms in Jeju Island, Korea. The genetic marker set was composed of 11 ISAG microsatellite (MS) markers, 11 SAES MS markers selected by our preliminary analysis for population diversity of JBC, and two major coat color related genes: $M C 1 R$ and ASIP. The results showed a combined non-exclusion probability for first parent (NE-P1) that was higher than that recommended by ISAG (above 0.9995 ), and a combined non-exclusion probability for sib identity of $5.3 \times 10^{-10}$. Parentage analysis showed that the cases identified the candidate's father only $(77.0 \%)$, mother only $(54.0 \%)$, and both parents $(40.5 \%)$ in the candidate offspring population. The ET and AI calves were identified as $14.7 \%$ in the in vitro fertilized eggs provided and $32.4 \%$ in total population, respectively. However, the result from ISAG marker analysis showed 3 identical allele-combinations in 7 calves, and that from ISAG/SAES MS marker combination also showed 1 identical allele-combination in 2 calves. Data from MS and coat-color gene analyses provided information for complete identification of all animals tested. Because the present JBC population was mostly bred using small nuclear founders through bioengineering techniques such as $\mathrm{AI}$ and ET, the genetic diversity levels obtained from MS analysis in the JBC population were relatively lower than those of other cattle populations, including Hanwoo. The results suggested that the more efficient marker combinations, including coat color related genotypes, should be studied and used for constructing a system for identification and molecular breeding of JBC as well.
\end{abstract}

Key words : $M C 1 R, A S I P$, microsatellite, parentage, Jeju Black cattle

\section{서 론}

사람이나 동물의 친자검정은 전통적으로 혈액형이나 혈액 단백질 분석방법에서 유전정보를 암호화하는 분자유전학 분 석기술의 발달로 유전자 분석이 주를 이루고 있다. 최근 인간 의 법의학적 검증에서 DNA 분석기법, 특히 MS의 반복양상에 따른 유전자형 분석이 공식 활용되면서 그 활용영역이 점차 확대되어 가축 품종들의 유연관계, 혈통 증명, 집단 식별 및 개체추적과 친자확인 등에 광범위하게 이용되고 있다 $[2,6,14$, $17,25,26]$. 이와 함께 한우의 황모색처럼 품종의 특성을 반영하 는 특정 유전자의 단일염기변이(single nucleotide polymorphism, $\mathrm{SNP})$ 와 부계( $\mathrm{Y}$ 염색체)나 모계(mtDNA) 유전을 통해 자손으로 전달되는 유전자의 다형성들은 검증 대상에서 특이적으로 중요한 정보의 보유여부를 판독할 수 있는 자료로

*Corresponding author

Tel : +82-64-754-5710, Fax : +82-64-754-5713

E-mail : lee6470@rda.go.kr
써 활용 가능성이 제기되었다[19,21,22,35,36].

제주흑우는 외형상 한우와 비슷하지만, 체형이 다소 작고 체모가 전반적으로 흑색을 나타내는 우리나라의 재래 소 중 한 품종이다. 1980년대 까지 유전자원의 중요성 보다 산업적 활용을 위한 개량을 지향하면서 한 때 심각한 멸종위기에 놓 였던 적도 있으나, 재래가축유전자원의 중요성에 대한 인식 이 전환되면서 1990년대 원종 수집과 축군 증식을 위한 연구 및 관리체계가 마련되었다. 현재까지 제주흑우 품종 단독으 로 산업화를 진행할 규모에는 이르지 못하였으나, 사육을 희 망하는 농가가 점차 증가하고 있으며, 수정란이식(ET)과 인공 수정(AI) 등을 통해 소수 농가에 일부 보급되고 있다. 제주흑 우의 품종 식별 및 혈통관리에서 가장 중요한 선결과제 중 하나는 타 품종 교배에 의해 생산된 흑색 교잡우와의 구분에 있다. 우리나라에 도입된 외래 소 품종 중 Holstein과 Angus 등은 우성흑모색을 지니고 있으며, 이들 품종과 한우의 교잡 1 세 $\left(\mathrm{F}_{1}\right.$, 일명 먹통, 먹우로 불림)는 전신 흑색을 나타내어 모색 만으로는 제주흑우 명확히 구분되지 않는다. 또한 초지가 풍 
부한 제주도에서는 유입된 외래 소와의 교잡에서 다양한 형 태의 교잡우들과 하절기에 공동 방목되고 있어 이들과의 명 확한 식별을 위한 유전자 분석 자료체계가 요구되고 있는 실 정이다.

소의 모색은 품종을 식별하는 중요한 표현형질로 간주되고 있다. 포유류에서 모색의 발현은 eumelanin과 pheomelanin 두 가지 색소의 발현 수준과 색소체(melanosome)을 함유하고 있는 색소세포(melanocyte)의 분포에 의해 결정되며, 100 여 가지 유전자의 상호작용에 의해 결정되며, 특히 Extension, Agouti 유전자의 다형성은 흑색, 황적색으로 구분되는 기본 바탕색을 결정하는 주요인으로 작용하는 것으로 알려져 있다 $[13,20,24,26,30]$. 현재까지 제주흑우에 대한 모색 유전자의 분 포에 대한 연구에서 일차적으로 Extension 좌위에 암호화되어 있는 melanocortin-1 receptor (MC1R) 유전자형은, 열성동형접 합자 $(e A)$ 가 주로 나타나는 한우와 달리 야생형 대립인자 $\left(E^{\dagger}\right)$ 가 주 대립인자로 알려져 있다. 또한 육성단계에서 Holstein이나 Angus 교잡이 의심되는 우성흑모색대립인자 $E^{D}$ 가 일부 발견 되고 있다[12,18,22]. $\mathrm{aMSH}-\mathrm{MC1R}$ 결합에 길항작용을 나타내 는 Agouti는 agouti signaling inducible peptide (ASII) 유전자에 암호화되어 있고, $\mathrm{MC} 1 \mathrm{R}$ 과의 결합을 통해 tyrosinase에 의한 eumelanin의 합성을 저해하여 황-적색 계열의 pheomelanin 의 양이 상대적으로 증가하고[1,10,11,29], 소 Normande 품종 에서 약 1.2-kb L1-BT retroposon의 삽입에 의해 brindle 양상 을 나타내는 $A^{B r}$ 대립인자가 출현하나 Holstein 품종에서는 $A^{B r}$ 유전자형이 전혀 발견되지 않는다고 보고하였다[11]. Holstein, Angus 등은 대부분 $M C 1 R$ 의 우성흑모색대립인자 $\left(E^{\natural}\right)$ 를 보유하고 있다.

제주흑우의 선별에 있어 Holstein나 Angus×한우 등의 $\mathrm{F}_{1}$ 와 의 구분이 선결과제이며, 아울러 20세기에 제주도에 도입된 Hereford, Simmental 등의 황갈색, 적갈색 품종과 Charolais, Brahman 등의 품종들, 현재 제주도에서 가장 높은 빈도로 사 육되고 있는 한우 등과 명확한 구분을 위해서는 $M C 1 R$ 뿐만 아니라 다양한 유전자 marker에서 수집한 정보의 조합이 필요 하다. 이에 본 연구는 $\mathrm{MS}$ 유전자형과 $M C I R, A S I P$ 유전자형 분석결과들의 조합을 통해, 그 동안 제주흑우를 수정란이식이 나 인공수정을 통해 공급 받은 농가에서 수집한 흑모색 후보 축군을 대상으로 수정란이식, 인공수정에 의해 생산된 제주흑 우 후대들을 추적하고자 수행하였다.

\section{재료 및 방법}

\section{공시동물과 DNA 추출}

본 연구의 수행을 위해 먼저 농촌진흥청 국립축산과학원 난지축산시험장(Subtropical Animal Experiment Station, National Institute of Animal Science, RDA; SAES)과 제주특 별자치도 축산진흥원(Livestock Promotion Institute, Jeju-do)
에서 수정란 생산과 인공수정에 이용되었던 종모우 10 두, 채 란을 위해 호르몬 처리에 이용된 종빈우 84두에서 전혈을 채혈 하거나 DNA를 분양받았다. 또한 상기 두 기관에서 생산한 수 정란이나 인공수정용 정액을 공급받은 농가, 육성우 단계에서 이를 구입한 농가 등에서 외형상 흑모색을 나타내거나 인공수 정이나 수정란이식에 의해 생산된 것으로 관리되고 있는 소, 해당 소를 생산한 대리모, 인공수정에 활용된 종빈우들을 대상 으로 총 296두의 말초혈액을 채취하였다. 전혈에서 DNA 분리 는 Sambrook 등[31]의 방법을 변형하여 수행하였으며, 분리한 DNA는 NanoDrop ND-1000 spectrophotometer (NanoDrop Technology, USA)로 흡광도를 측정한 후 $\mathrm{A}_{260} / \mathrm{A}_{280}$ 와 $\mathrm{A}_{230} /$ $\mathrm{A}_{280}$ 이 모두 1.8 이상인 $\mathrm{DNA}$ 들을 $50-60 \mathrm{ng} / \mu \mathrm{l}$ 로 희석하여 $\mathrm{PCR}$ 반응의 주형으로 이용하였다.

\section{Microsatellite 유전자형의 결정}

분석에 이용한 MS marker는 국제동물유전학회(International Society of Animal Genetics, ISAG)에서 소의 유전적 다양성 연구와 친자검정 등에 활용을 권장하고 있는 ISAG MS marker 11 종(TGLA227, BM2113, TGLA53, ETH10, SPS115, TGLA126, TGLA122, INRA23, ETH3, ETH225, BM1824)과 제 주흑우 다양성 분석과 친자검정을 위해 사전 연구에 의해 선 발된 SAES MS marker 11종(BMS1907, BMS4028, BMS1580, BMS2060, DIK4591, DIK4460, DIK3027, BL1134, DIK4224, IDVGA-37, MNS-2)을 추가 선정하였다. MS primer 쌍 중 하 나를 FAM, HEX, NED, TAMRA 등으로 5'형광 표지하였다. $\mathrm{MS}$ 증폭은 먼저 부모집단을 이용하여 개별적인 MS 증폭과 다형성 조사를 수행한 후 multiplex PCR 조합을 구성하여 수 행하였다. PCR 반응은 $50 \mathrm{ng}$ 의 genomic DNA 용액에 $1 \times$ PCR buffer, $125 \mathrm{mM}$ dNTP, 0.3 Unit HotStart Taq DNA polymerase (Bioneer, Korea)에 초기 실험에서 선정한 각각의 MS marker에 대한 primer들을 첨가하고, 멸균 증류수를 첨가하 여 최종 $10 \mu \mathrm{l}$ 가 되게 하여 준비하였다. 준비된 반응액에 대한 PCR 증폭은 PTC-200 thermal cycler (Bio-Rad, USA) 상에서 $95^{\circ} \mathrm{C}$ 에서 5 분간 초기변성, $94^{\circ} \mathrm{C} 45$ 초-annealing 온도에서 75 초-72 ${ }^{\circ} \mathrm{C}$ 90초로 구성된 cycle을 35 회 반복 수행하고 $72^{\circ} \mathrm{C}$ 에서 10 분간 최종 신장하였다. 증폭산물은 5 배 또는 10 배 희석 후 ET-400R size standard (Amersham Biosciences, USA)와 혼합 하여 MegaBase1000 automated DNA Sequencer (Amersham Biosciences, USA) 상에서 분리하고, Genetic Profiler (Amersham Biosciences, USA)를 이용하여 marker의 유전자 형을 결정하였다. 실험과정 상의 오차를 줄이기 위해 모든 종 모우, 수정란 생산용 공란우들을 96 well plate에 3회 이상 탑 재하여 유전자형의 동일한 출현 여부를 점검하였다. MS 유전 자형 분석은 준비한 시료들을 2 회 반복 수행하였으며, 동일한 결과를 나타내지 않는 시료에 대해서는 단일 MS 분석을 통해 data를 보정하였다. 


\section{$M C 1 R, A S I P$ 유전자형의 결정}

모색 관련 유전자형 결정에서 $M C 1 R$ 과 $A S I P$ 유전자의 분석 은 기존의 보고[11,12]에 준하여 수행하였다. 각각의 유전자에 대한 PCR 증폭 산물에 대해 $A S I P$ 는 바로 $1.5 \%$ agarose gel 상에서 전개하여 유전자형을 결정하였고, $M C I R$ 은 $A l u l, M s p$ 제한효소를 처리하여 $37^{\circ} \mathrm{C}$ 에서 overnight 반응한 후 $2.5 \%$ agarose gel 상에서 전기영동 확인하였다.

\section{대립인자형의 결정 및 친자검정}

MS 대립인자형과 $M C 1 R, A S I P$ 유전자형 분석에서 산출된 모든 좌위에 대한 대립인자 출현빈도와 이형접합성(heterozygosity; He), 다형정보량(polymorphic information contents; $\mathrm{PIC})$, 부권부정 율(exclusion probability, $\mathrm{PE}$ )을 산출하였다. 부 권부정율은 부모에 대한 정보가 전혀 없는 경우(NE-1P), 한쪽 부모를 알고 있을 때 다른 한쪽의 부권부정율(NE-2P)는 경우, 양친과 자손을 모두 알고 있는 경우(NE-PP)의 부권부정율을 산출하였다. 좌위별 유전자형에 대한 정보의 산출과 친자검정 은 CERVUS 3.0.3 [15]을 이용하였다. 조사된 개체들 중 유전자 형이 동일한 개체의 확인은 CERVUS package 내 동일성검사 (Identity Analysis) program을 이용하였다. 수정란이식과정 에서 공란우로 이용된 모든 종빈우를 후보 모(candidate moth$\mathrm{er}$ )로 선정하고, 수정란이식과 인공수정을 위해 정액채취에 이 용된 모든 종모우를 후보 부(candidate father)로 선정하고 친 자검정(Parentage Analysis) program을 이용하여 95\% 신뢰수 준에서 검출되는 모든 후모 부모를 찾아낸 후 수정란 이식 및 인공수정의 판독에 이용하였다.

\section{결과 및 고찰}

1990년대 멸종위기인 제주흑우의 복원을 위해 농촌진흥청 국립축산과학원 난지축산시험장과 제주특별자치도 축산진흥 원에서만 보존되고 있던 제주흑우의 산업화에 대한 요구가 증가함에 따라 2000년 이후 제주흑우 정액과 수정란이 농가 보급이 진행되었다. 수정란이식 및 인공수정에 의해 생산된 농가 보유 제주흑우의 후대우들에 대한 분자유전학적 검증과 효율적인 관리체계의 도입을 위해 해당 농가와 육성우 단계에 서 이를 구입한 농가에서 외형상 제주흑우와 유사한 개체들과 후대우로 관리되고 있는 개체들의 DNA를 수집하여 본 연구 를 수행하였다.

\section{$\mathrm{MS}$ 다형성 정보와 제주흑우의 유전적 다양성}

분석에 이용한 MS marker 22종과 $M C 1 R, A S I P$ 유전자 모 두 집단 내에서 다형현상을 나타내었다. Table 1은 22종의 MS marker에 대한 분석에서 발견된 대립인자의 수와 이형접합성 의 빈도 $(\mathrm{Ho}, \mathrm{He})$, 다형정보량 $(\mathrm{PIC})$ 등을 종모우로 구성된 후보 부 집단, 종빈우들로 이루어진 후보 모 집단과 전체집단으로
구분하여 나타낸 것이다. 각각의 MS 유전자 좌위에서 평균 대립인자의 수는 8.77 개이고, 관찰 이형접합성 $(\mathrm{Ho})$ 의 평균은 0.677 , 기대 이형접합성 $(\mathrm{He})$ 의 평균은 0.672 , 다형정보량의 평 균은 0.629 로 조사되었다. TGLA53 marker는 17개 대립인자가 발견되었고, MNS-2는 대립인자가 4 개로 가장 적었다. 분석된 22종의 marker 중 ETH225, TGLA126, DIK3027 등은 HardyWeinberg 평형에 대한 유의차를 나타내었다.

유전자 marker별로 다형성 정보량을 보여주는 PIC의 경우 전체 22종의 MS 분석에서 후보 부는 0.555 로 후보 모집단의 0.616 이나 전체집단의 0.629 에 비해 다소 낮은 결과를 보여주 었다. 정액생산에 이용되었던 종모우 10 두에 대한 분석결과 에서 MS marker 중 BM1824, ETH225, TGLA227, BMS1907, BMS1580, DIK4591 등 6 종은 PIC의 값이 0.5 이하로 나타나 marker로서의 정보력이 다소 떨어지는 경향을 보였으며, 이 중 BM1824, BMS1907, BMS1580 등은 공란우 집단과 전체 조 사 축군에서도 PIC가 0.5 이하로 확인되었다. PIC가 0.7 이상 인 경우 유전자 분석에 의한 친자검정 및 개체식별 뿐만 아니 라 유전질환모델 동물의 개발이나 분자육종 marker로서의 개 발 등에도 유용하게 이용될 수 있을 것으로 보고한 바 있다[4]. ETH3, INRA23, TGLA53 등의 PIC는 후보 부, 모, 전체 축군에 서 모두 PIC가 0.7 이상으로 확인되었고, TGLA122는 후보 모 와 전체 축군, TGLA126은 후보 부와 전체축군에서, DIK4460 은 전체 축군에서 0.7 이상으로 확인되었다.

Table 2는 ISAG marker와 SAES marker, ASIP, MCIR 등을 분석했을 때 전체 집단에 대한 친자검정 시 marker 조합의 친 자검정능력을 나타내는 부권부정률 $(\mathrm{PE})$ 과 동일개체부정율 (NE-I) 등을 나타낸 것이다. 먼저, 국제동물유전학회에서 권장 하는 ISAG MS 11 종에서 산출된 data를 조합한 경우 PE 중 부모에 대한 정보가 없는 상태에서의 부권부정율인 NE-1P는 0.99027 정도로 확인되었다. 이는 SAES MS 11 종에서 얻어진 NE-1P 0.95056 보다 높은 수치이나, 국제권장 수준인 0.9995 $\mathrm{PE}$ 보다는 다소 낮은 수준을 보였다. ISAG marker와 SAES marker를 조합한 경우 NE-1P가 국제권장수준보다 높아졌고, 여기에 제주흑우 품종 확인에 있어 핵심요건인 모색관련 유전 자 2종, $M C 1 R$ 과 $A S I P$ 의 결과를 조합하면 NE-1P의 수준은 0.9996 이상으로 매우 좋은 marker set이 구성됨을 보여주었다.

ISAG MS marker의 경우 한우를 비롯한 여러 품종에서 11 종의 marker 전체 내지는 일부에 대한 분석 결과들이 보고되 었다. Oh 등[26]은 ISAG marker를 활용해 국내 한우 브랜드 집단간 유연관계와 유전적 구조를 분석한 바 있다. 발견된 대 립인자의 수는 7개(BM1824)에서 23개(TGLA122)로 marker당 평균 12.27 개씩 발견되고 PIC의 평균은 $0.728, \mathrm{He}$ 는 9 개의 브 랜드에서 0.756 에서 0.773 로 보고되었다. Cho 등[7]의 ISAG 11종 MS marker에 대한 한우와 Holstein에 대한 연구에서 한 우는 대립인자의 수가 5개(BM1824, BM2113, ETH225, TGLA126)에서 11개(TGLA53)이며 marker 당 평균 6.72개의 
Table 1. Frequencies of allele, heterozygosity in candidate parents and overall populations tested

\begin{tabular}{|c|c|c|c|c|c|c|c|c|c|c|c|c|c|}
\hline \multirow{2}{*}{ Locus } & \multicolumn{4}{|c|}{ candidate fathers $(n=10)$} & \multicolumn{4}{|c|}{ candidate mothers $(n=84)$} & \multicolumn{5}{|c|}{ overall $(n=390)$} \\
\hline & $\mathrm{k}$ & Ho & $\mathrm{He}$ & PIC & $\mathrm{k}$ & Ho & $\mathrm{He}$ & PIC & k & Ho & $\mathrm{He}$ & PIC & $\mathrm{HW}^{1}$ \\
\hline BL1134 & 4 & 0.800 & 0.658 & 0.578 & 5 & 0.707 & 0.727 & 0.687 & 6 & 0.726 & 0.728 & 0.685 & NS \\
\hline BM1824 & 3 & 0.100 & 0.353 & 0.303 & 5 & 0.512 & 0.587 & 0.525 & 7 & 0.401 & 0.446 & 0.414 & NS \\
\hline BM2113 & 5 & 0.600 & 0.568 & 0.508 & 8 & 0.774 & 0.694 & 0.655 & 9 & 0.688 & 0.646 & 0.612 & NS \\
\hline BMS1580 & 2 & 0.200 & 0.209 & 0.178 & 4 & 0.333 & 0.316 & 0.286 & 9 & 0.487 & 0.511 & 0.433 & NS \\
\hline BMS1907 & 4 & 0.700 & 0.563 & 0.498 & 5 & 0.506 & 0.558 & 0.474 & 8 & 0.534 & 0.542 & 0.487 & NS \\
\hline BMS2060 & 4 & 0.900 & 0.658 & 0.578 & 5 & 0.59 & 0.557 & 0.518 & 7 & 0.599 & 0.586 & 0.523 & NS \\
\hline BMS4028 & 5 & 0.800 & 0.752 & 0.668 & 7 & 0.765 & 0.736 & 0.697 & 11 & 0.734 & 0.703 & 0.671 & NS \\
\hline ETH10 & 4 & 0.800 & 0.689 & 0.603 & 6 & 0.714 & 0.64 & 0.582 & 8 & 0.721 & 0.712 & 0.665 & NS \\
\hline ETH225 & 4 & 0.500 & 0.489 & 0.420 & 5 & 0.619 & 0.635 & 0.579 & 8 & 0.622 & 0.579 & 0.535 & $* *$ \\
\hline ETH3 & 5 & 0.700 & 0.795 & 0.713 & 7 & 0.81 & 0.782 & 0.743 & 8 & 0.749 & 0.745 & 0.712 & NS \\
\hline IDVGA-37 & 3 & 1.000 & 0.668 & 0.559 & 5 & 0.544 & 0.625 & 0.550 & 7 & 0.657 & 0.649 & 0.578 & NS \\
\hline INRA23 & 6 & 0.900 & 0.858 & 0.789 & 6 & 0.702 & 0.77 & 0.728 & 10 & 0.802 & 0.804 & 0.778 & NS \\
\hline DIK3027 & 4 & 0.700 & 0.684 & 0.584 & 6 & 0.693 & 0.743 & 0.698 & 7 & 0.642 & 0.7 & 0.655 & $* * *$ \\
\hline DIK4460 & 4 & 0.500 & 0.647 & 0.544 & 7 & 0.74 & 0.734 & 0.688 & 7 & 0.761 & 0.759 & 0.722 & NS \\
\hline DIK4224 & 5 & 0.700 & 0.626 & 0.561 & 9 & 0.646 & 0.608 & 0.581 & 10 & 0.694 & 0.687 & 0.653 & NS \\
\hline DIK4591 & 3 & 0.500 & 0.468 & 0.381 & 5 & 0.524 & 0.49 & 0.443 & 6 & 0.582 & 0.562 & 0.509 & NS \\
\hline MNS-2 & 3 & 0.800 & 0.653 & 0.548 & 4 & 0.642 & 0.635 & 0.557 & 4 & 0.59 & 0.563 & 0.501 & NS \\
\hline SPS115 & 5 & 0.700 & 0.616 & 0.544 & 6 & 0.762 & 0.708 & 0.656 & 8 & 0.756 & 0.736 & 0.699 & NS \\
\hline TGLA122 & 7 & 0.800 & 0.726 & 0.658 & 7 & 0.845 & 0.827 & 0.800 & 17 & 0.809 & 0.8 & 0.777 & NS \\
\hline TGLA126 & 5 & 0.700 & 0.805 & 0.729 & 5 & 0.714 & 0.731 & 0.685 & 7 & 0.774 & 0.779 & 0.741 & * \\
\hline TGLA227 & 4 & 0.600 & 0.574 & 0.476 & 6 & 0.655 & 0.631 & 0.566 & 12 & 0.688 & 0.695 & 0.656 & NS \\
\hline TGLA53 & 7 & 0.900 & 0.858 & 0.791 & 12 & 0.893 & 0.865 & 0.845 & 17 & 0.886 & 0.854 & 0.840 & NS \\
\hline overall mean & 4.36 & 0.677 & 0.633 & 0.555 & 6.13 & 0.668 & 0.664 & 0.616 & 8.77 & 0.677 & 0.672 & 0.629 & \\
\hline
\end{tabular}

k, number of allele found; Ho, observed heterozygosity; He, expected heterozygosity; PIC, polymorphic information content; HW, Hardy-Weinberg equilibrium.

$1, *<0.05 ; * *<0.01 ; * *<0.001 ; \mathrm{NS}$, not significant.

Table 2. Combined non-exclusion probabilities obtained from the analyses

\begin{tabular}{|c|c|c|c|c|c|}
\hline Molecular marker & NE-1P & NE-2P & NE-PP & NE-1 & NE-SI \\
\hline ISAG MS markers & 0.9902701 & 0.9996973 & 0.9999991 & $7.6 \times 10^{-12}$ & 0.9999234 \\
\hline NIASJ MS markers & 0.9505602 & 0.9965295 & 0.9999338 & $4.4 \times 10^{-10}$ & 0.9997092 \\
\hline combined ISAG+NIASJ & 0.9995189 & 0.9999989 & $3.63 \times 10^{-12}$ & $8.58 \times 10^{-20}$ & 0.9999999 \\
\hline$A S I P$ & 0.0150162 & 0.0791412 & 0.1396615 & 0.3015486 & 0.1620365 \\
\hline$M C 1 R$ & 0.1812402 & 0.3201026 & 0.4682533 & 0.7675028 & 0.4929075 \\
\hline overall markers & 0.9996120 & 0.9999993 & $7.13 \times 10^{-12}$ & $7.69 \times 10^{-21}$ & $5.30 \times 10^{-10}$ \\
\hline
\end{tabular}

대립인자가 출현하고, $\mathrm{PIC}$ 는 평균 $0.684, \mathrm{He}$ 는 0.732 로 확인되 었고, 젖소는 4개(SPS115)에서 9개(TGLA227)의 대립인자가 marker 당 평균 5.82 개씩 출현하고 평균 $\mathrm{PIC}$ 는 $0.639, \mathrm{He}$ 는 0.692 로 보고하였다. 두 연구에서 한우 품종에서의 대립인자 수와 PIC의 차이는 결국 분석 시료 수와 sampling 지역의 차 이에서 비롯한 결과라 하겠다. Yoon 등[36]의 보고에서는 본 연구와 동일한 3종이 부분적으로 이용되었고, 이 중 TGLA122 가 전 세계적으로 분포하는 19품종에서 대립인자 수가 26개로 가장 많고 TGLA227은 18 개로 가장 적게 출현하며, 전체 11종 의 marker를 통해 산출된 관찰 이형접합성은 0.578 , 평균 대립 인자 수는 6.36으로 보고하였다. ISAG MS 5종과 INRA63 등을
이용한 소 품종별 대립인자 분포 분석에서 한우와 중국연변황 우가 Holstein이나 일본흑모화우에 비해 다양성이 높은 것으 로 보고하였다[16]. 본 조사에서는 전체 축군 중 제주흑우 종모 우와 종빈우의 대립인자는 4(BMS1580, MNS-2) 12개 (TGLA53)로 marker당 평균 6.23개가 관찰되었고, 평균 PIC는 $0.613, \mathrm{He}$ 는 0.666 으로 확인되었다. 즉, 한우에 비해 출현 대립 인자의 수가 적고, $\mathrm{PIC}, \mathrm{He}$ 모두 낮은 수치를 보이는데, 한우는 200 만 두를 상회하는 규모이며, 일정기간 경과 후 보증종모우 를 지속적으로 교체해주고 있으나, 제주흑우는 대략 300 두 정 도의 소규모 축군이며 핵심 종모우는 2 혈통을 중심으로 육성 되었음을 감안할 때 제주흑우의 유전적 다양성이 한우에 비해 


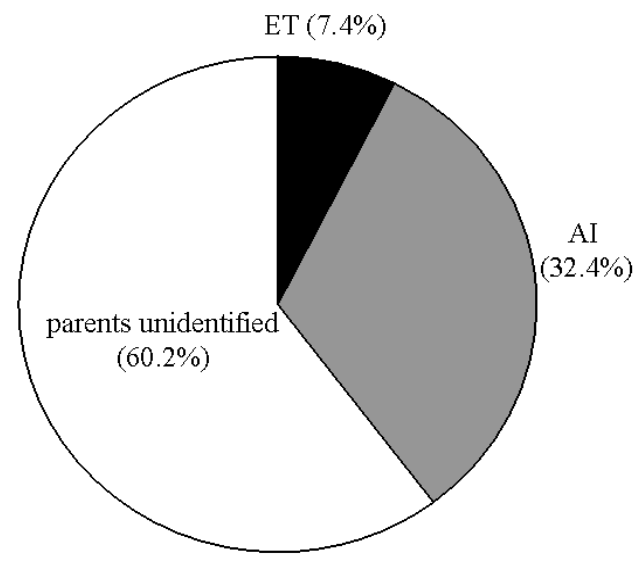

Fig. 1. Frequencies of ET, AI and unidentified calves found in the candidate offspring collected from farms. ET, embryo transfer; $\mathrm{AI}$, artificial insemination.

낮은 수준을 보이는 것은 당연한 결과라 하겠다.

\section{유전자 친자검정}

총 24종의 유전자 marker들(MS 22종, $M C 1 R, A S I P$ 에 대한 분석에서 얻어진 모든 정보를 이용하여 유전자 친자검정을 수행하였다. $95 \%$ 의 신뢰수준에 대한 후보축군에 대한 부모확 인 과정에서 후보 모가 확인된 경우는 163 두(54.6\%), 후보 부 가 확인되는 경우가 233 두(74.8\%)였으며, 부모가 동시에 확인 되는 경우는 123 두 $(42.3 \%)$ 로 확인되었다. 자손의 유전자형이 모두 후보 부모의 유전자형 내에 분포하는 멘델 유전 상에 위치하는(trio-mismatch $=0$ ) 후보축은 수정란이식 생산축으 로, 반면 후보 부와 자손의 mismatch가 0이면서 종빈우가 농 장 보유축에서 발견되거나 제주흑우 보유기관인 국립축산과 학원 제주출장소나 제주도 축산진흥원 집단에서 근연인 개체 가 발견되는 경우만 인공수정 생산축으로 판독하였다.

22 종의 MS 유전자형을 이용한 친자감정에서 제 1 후보 모와 제 1 후보 부가 상기 두 기관의 공란우와 종모우에 해당하면서 mismatch가 전혀 없는 trio-mismatch $=0$ 인 개체들은 총 25 두 가 발견되었으나, 이들 중 2 두는 $M C I R, 1$ 두는 $A S I P$ 유전자형 에서 부모의 유전자형과 일치하지 않아 수정란이식 축군에서 탈락되어 최종 22두를 수정란이식 자손으로 판정하였다. 이는 전체 분석 대상에서 $7.4 \%$ 에 해당하는 낮은 수치였으나, 2004 년부터 2006년까지 공급된 수정란의 수가 150개로 확인되어 공급수정란 대비 송아지 확인 비율은 $14.7 \%$ 의 성적을 보여 주었다. 한편 채외 수정란(in vitro produced, IVP, embryo)의 경우 $\mathrm{AI}$ 에 비해 낮은 수태율, 임신기간의 증가뿐만 아니라 과 체중, 높은 생시 사망률, 선천적 이상발생 등이 보고되고 있고 [3,8,28,32-34], 조사과정 중 수정란이식 후 재발정, 난산 후 조 기폐사, 거대출생, 허약 등에 의한 생시 또는 생후 폐사된 개체 들이 다수 있었고, 정상출생 후 비육출하된 개체들의 누락 등 을 반영하면, 본 연구의 친자감정에서 확인된 개체들만 수정
란이식의 성공 사례라 단정하는 것은 많은 무리가 있다고 하 겠다.

후보 부와 자손의 유전자형에서 신뢰수준이상으로 검출되 는 233 두 중 mismatch가 전혀 없고, 모가 농가집단에서 확인되 거나, 축산진흥원이나 국립축산과학원 난지축산시험장에서 유래된 것이 유력한 96두 인공수정에 의한 생산 자손으로 판명 하였다. 반면 본 연구에서는 후보 부와 후손의 mismatch가 없 더라도 후보 모가 확인되지 않거나 유연관계가 먼 경우는 인공 수정 생산축으로 판정하지 않았다. 이는 후보 부에 대한 추적 에서 후손은 부모로부터 물려받은 유전체 정보를 모두 보유하 고 있기 때문에 둘 중 하나만 후모 부에 일치하더라도 해당 좌위에서 mismatch가 없는 것으로 판독되는 데서 오는 오류를 차단하기 위해서였다. 하지만 제주흑우 정액을 이용한 인공수 정이 개시된 2000년대 초반이며 당시에 인공수정에 활용된 종 빈우 중 일부가 현재는 남아있지 않아 시료채취에서 누락되었 을 가능성이 있기 때문에, 실제 인공수정에 의해 생산된 후손 의 수는 더 많은 것으로 추정되며, 이들을 정확한 판독을 위해 서는 부, 모계에 의해 유전되는 성염색체와 mtDNA에 대한 유전자 정보가 추가되어야 할 것으로 사료된다.

유전자 친자검정에 있어 ISAG 11종의 marker만을 이용한 분석에서는 총 41 두가 수정란이식으로 판정되는(trio-mismatch $=0$ ) 결과를 얻었다. 반면 SAES MS 11종을 추가했을 때 수정란이식 개체는 25 두, $M C 1 R$ 과 $A S I P$ 까지 추가한 경우 최 종 22두가 수정란이식에 의해 생산된 개체들로 최종 확인되었 다. 이상의 결과들은 Table 2에 나타난 바와 같이 NE-1P에 해당하는 부권부정율이 국제권장기준인 0.9995보다 낮은 경 우 친자검정에서 오류가 발생할 수 있다는 기존 연구보고들 $[5,7,9]$ 와 유사한 결과라 하겠다. $\operatorname{Lim}$ 등[23]은 한우 생산이력 제에 활용 가능한 MS 분석체계의 제안에서 MS marker의 구 성에 따라 대상 집단에 대한 정보력에 차이를 보임에 따라 적정 집단의 다양성 정보를 보다 효율적으로 분석할 수 있는 체계의 구축을 제안한 바 있다.

제주흑우는 1980년대 이후 보존과 육성에 대한 필요성이 제기된 이후, 유전적 특성 규명과 더불어 산업화의 선결요건 인 개체군의 증식을 위해 다각적인 노력을 기울여 왔다. 본 연구에서 유전자 친자검정을 통해 수정란이식 개체들과 인공 수정 개체들을 성공적으로 구분해 냄으로써 외형상 제주흑우 와 혼란을 일으키는 교잡우 개체들로부터 제주흑우의 보호와 혈통보존에 기여할 것이다. 아울러 사육이나 인공수정을 통한 증식을 희망하는 농가 집단에 대한 사전 DNA 확보가 매우 중대한 사안이 될 것이며, 현재 보유하고 있는 축군 전체를 대상으로 보다 많은 수의 MS marker의 정보, 모색관련 유전자 의 특이 SNP, 성염색체와 mtDNA 등 부계, 모계 특이 marker 에 대한 자료를 적절하게 조합한 유전자분석체계가 구축된다 면, 친자검정, 개체식별 등 혈통정립 사업뿐만 아니라, 제주흑 우 생산이력추적제나 품종인증을 위한 기틀을 마련하는 데 
크게 기여할 것으로 사료된다.

\section{감사의 글}

본 연구는 농림수산식품부 농림기술개발사업과 농촌진흥 청 국립축산과학원 경상과제(200901OFT072149135)의 지원에 의해 이루어진 것임.

\section{References}

1. Argeson, A. C., K. K. Nelson, and L. D. Siracusa. 1996. Molecular basis of the pleiotropic phenotype of mice carrying the hypervariable yellow (Ahvy) mutation at the agouti locus. Genetics 142, 557-567.

2. Arranz, J. J., Y. Bayon, and F. San Primitivo. 1996. Comparison of protein markers and microsatellites in differentiation of cattle populations. Anim Genet. 27, 415-419.

3. Behboodi, E., G. B. Anderson, R. H. BonDurant, S. L. Cargill, B. R. Kreuscher, J. F. Medrano, and J. D. Murray. 1995. Birth of large calves that developed from in vitro-derived bovine embryos. Theriogenology 44, 227-232.

4. Chae, Y., D. Kim, H. Kim, M. Lee, W. Hwang, B. Lee, H. Youn, and H. Lee. 1999. Paternity test in dogs by microsatellite allele analysis. Kor. J. Vet. Res. 39, 213-219.

5. Cho, G. J. 2004. Parentage testing for thoroughbred horse by microsatellite DNA typing. Kor. J. Anim Sci. Technol. 46, 129-136.

6. Cho, G. J., Y. J. Yang, and B. H. Kim. 2003. A case of parentage testing in the thoroughbred horse by microsatellite typing. Kor. J. Vet. Res. 43, 25-30.

7. Cho, G., Y. Yang, and K. Lee. 2004. Analysis of genetic diversity for cattle parentage using microsatellite markers. Kor. J. Vet. Res. 44, 287-292.

8. De Kruip, Th. A. M. and J. H. G. den Daas. 1997. In vitro produced and cloned embryos: effects on pregnancy, parturition and offspring. Theriogenology 47, 43-52.

9. Dimsoski, P. 2003. Development of a 17-plex microsatellitepolymerase chain reaction kit for genotyping horses. Croat. Med J. 44, 332-335.

10. Furumura, M., C. Sakai, Z. Abdel-Malek, G. S. Barsh, and V. J. Hearing. 1996. The interaction of agouti signal protein and melanocyte stimulating hormone to regulate melanin formation in mammals. Pigment Cell Res. 9, 191-203.

11. Girardot, M., S. Guibert, M. P. Laforet, Y. Gallard, H. Larroque, and A. Oulmouden. 2006. The insertion of a full-length Bos taurus LINE element is responsible for a transcriptional deregulation of the Normande Agouti gene. Pigment Cell Res. 19, 346-355.

12. Han, S. H., Y. H. Kim, I. C. Cho, B. G. Jang, M. S. Ko, H. Y. Jung, and S. S. Lee. 2008. Analysis of the genotype distribution in cattle breeds using a double mismatched primer set that discriminates the $M C 1 R$ dominant black allele. Kor. J. Anim Sci. Technol. 50, 633-640.

13. Hearing, V. J. and K. Tsukamoto. 1991. Enzymatic control of pigmentation in mammals. FASEB J. 5, 2902-2909.

14. Ji, H., E. Kim, K. Lee, T. Kang, J. Lee, H. Shin, L. Kim, and Y. Yun. 2007. Beagle dogs parentage testing by using 22 ISAG microsatellite markers. Kor. J. Vet. Res. 47, 457-460.

15. Kalinowski, S. T., M. L. Taper, and T. C. Marshall, 2007. Revising how the computer program CERVUS accommodates genotyping error increases success in paternity assignment. Mol. Ecol. 16, 1099-1106.

16. Kim, K. S., J. H. Eum, and C. B. Choi. 2001. Genetic diversity of Korean cattle using microsatellite analysis. Kor. J. Anim Sci. Technol. 43, 599-608.

17. Kim, M. J., G. H. Li, J. D. Oh, K. H. Cho, G. J. Jeon, B. H. Choi, J. H. Lee, Y. S. Hong, H. S. Kong, and H. K. Lee. 2007. Characterization of a Korean traditional porcine breed using microsatellite markers and establishment of an individual identification system. Kor. J. Food Sci. Ani. Resour. 27, 150-156.

18. Kim, T. H., D. H. Yoon, E. W. Park, H. Y. Lee, S. J. Oh, I. C. Cheong, T. Y. Thak, K. N. Kim, and J. Y. Han. 2000. A study on genotype frequencies of the bovine melanocortin receptor 1 (MC1R) in cattle breeds. Kor. J. Anim Sci. Technol. 42, 735-744.

19. Kim, T. H., D. H. Yoon, H. S. Lee, I. C. Cheong, and J. K. Jo. 1997. Analysis of D-loop region sequences in mitochondrial genome of Korean native pig. Kor. J. Anim Sci. Technol. 39, 215-224.

20. Klungland, H., D. I. Vage, L. Gomez-Raya, S. Adalsteinsson, and S. Lien. 1995. The role of melanocyte-stimulating hormone (MSH) receptor in bovine coat color determination. Mamm Genome 6:636-639.

21. Lee, S. S., B. S. Yang, Y. H. Yang, S. Y. Kang, S. B. Ko, J. K. Jung, W. Y. Oh, S. J. Oh, and K. I. Kim. 2002. Analysis of melanocortin receptor 1 (MC1R) genotype in Korean Bridle cattle and Korean cattle with dark muzzle. Kor. J. Anim Sci. Technol. 44, 23-30.

22. Lee, S. S., Y. H. Yang, S. Y. Kang, W. Y. Oh, B. S. Yang, S. B. Ko, S. J. Oh, and K. I. Kim. 2000. Comparison of the genotype and frequencies of MSH receptor (MCIR) gene in Korean cattle, Cheju native black cattle, Japanese black and Japanese brown cattle. Kor. J. Anim Sci. Technol. 42, 253-260.

23. Lim, H. T., H. S. Min, W. G. Moon, J. B. Lee, J. H. Kim, I. C. Cho, H. K. Lee, Y. W. Lee, J. G. Lee, and J. T. Jeon. 2005. Analysis and selection of microsatellite markers for individual traceability system in Hanwoo. Kor. J. Anim Sci. Technol. 47, 491-500.

24. Lu, D., D. Willard, I. R. Patel, S. Kadwell, L. Overton, T. Kost, M. Luther, W. Chen, R. P. Woychik, W. O. Wilkison, and R. D. Cone. 1994. Agouti protein is an antagonist of the melanocyte-stimulating-horomone receptor. Nature 371, 799-802.

25. Mannen, H., S. Tsuji, F. Mukai, N. Goto, and S. Ohtagaki. 1993. Genetic similarity using DNA fingerprinting in cattle to determine relationship coefficient. J. Hered 84, 166-169.

26. Oh, J. D., H. S. Kong, J. H. Lee, S. J. Moon, G. J. Jeon, and H. K. Lee. 2007. The genetic relationship between regional 
population of Hanwoo brands (Korean Cattle) using microsatellite markers. Kor. J. Food Sci. Ani. Resour. 27, 357-362.

27. Olson, T. A. 1999. The Genetics of Cattle. Wallingford, Oxon, CAB International.

28. Park, Y. S. 2004. Effects of different blastocyst production techniques: in vivo, in vitro or nuclear transfer, on progeny, parturition and viability of Hanwoo. Kor. J. Emb. Trans. 19, 239-244.

29. Rieder, S., S. Taourit, D. Mariat, B. Langlois, and G. Guerin. 2001 Mutations in the agouti (ASIP), the extension $(M C 1 R)$, and the brown (TYRPI) loci and their association to coat color phenotypes in horses (Equus caballus). Mamm Genome $12,450-455$.

30. Rouzaud, F. and V. J. Hearing. 2005. Regulatory elements of the melanocortin 1 receptor. Peptides 26, 1858-1870.

31. Sambrook, J., E. F. Fritsch, and T. Manniatis. 1989. Molecular cloning: a laboratory mannual. 2nd Ed. Cold Spring Harbor Laboratory.

32. Sinclair, K. D., P. J. Broadbent, and D. F. Dolman. 1995.
In vitro produced embryos as a means of achieving pregnancy and improving productivity in beef cows. J. Anim Sci. $60,55-64$.

33. Song, S. H., S. K. Cho, S. R. Cho, B. W. Sim, D. W. Kang, K. H. Chung, D. S. Son, H. J. Lee, C. S. Park, and S. Y. Choe. 2000. Production of twin calves following transfer of Hanwoo embryos produced in vitro. Kor. J. Emb. Trans. 15, 47-56.

34. Yang, B. S., G. S. Im, and S. J. Park. 2001. Characteristics of Korean native, Hanwoo, calves produced by transfer of in vitro produced embryos. Anim Reprod Sci. 67, 153-158.

35. Yoon, D., E. W. Park, Y. M. Cho, I. C. Cheong, and S. K. Lim. 2007. Allele frequency of the bovine Y-chromosome microsatellite locus in the cattle breeds. Kor. J. Anim Sci. Technol. 49, 429-436.

36. Yoon, D., H. K. Lee, S. J. Oh, K. C. Hong, G. J. Jeon, H. S. Kong, and J. H. Lee. 2005. Genetic relationships of cattle breeds assessed by PCR-RFLP of the bovine mitochondrial DNA D-loop region. Asian-Aust. J. Anim Sci. 18, 1368-1374.

초록 : 제주흑우 집단에서 모색 관련 유전자와 microsatellite marker의 다형현상을 이용한 수정란이 식 및 인공수정 유래 후대우 검증

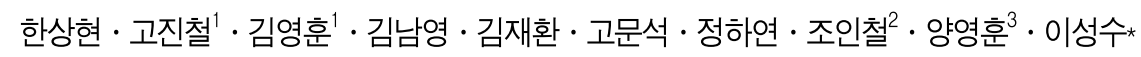

(농촌진흥청 국립축산과학원 난지축산시험장, ${ }^{1}$ 제주특별자치도 축산진흥원, ${ }^{2}$ 농촌진흥청 국립축산과학원 동물유전체과, ${ }^{3}$ 제주대학교 동물자원과학과)

농가에 보급된 제주흑우 수정란이식 및 인공수정 생산축의 확인을 위하여 분자유전학적 실험기법을 이용한 개체 추척을 수행하였다. 유전자 marker 체계는 ISAG 권장 MS marker 11종, 예비시험 후 선발된 SAES marker 11 종, 흑모색 관련 $M C 1 R$ 과 $A S I P$ 유전자들을 조합하여 분석하였다. 분석결과 부모 정보가 없는 상태에서의 부권 부정율이 국제권장기준보다 높은 수준을 보였으며, 형매간 동일개체출현률은 $5.3 \times 10^{-10}$ 으로 조사되었다. 친자검정 결과 후보축에 대한 후보 부, 모, 부모 모두가 확인되는 경우는 각각 $77.0,54.0,40.5 \%$ 였다. 부-모-자간 trio-mismatch가 전혀 없는 수정란이식 개체는 공급 수정란 대비 $14.7 \%$ 로 확인되었고, 전체 후보축군 중 $32.4 \%$ 는 후보 부와의 mismatch가 없는 인공수정에 의해 생산된 개체들로 판정하였다. ISAG marker들만을 분석한 결과에서는 7 두가 동일한 3 가지 유전자형 조합을 나타내었으나, ISAG/SAES marker들을 조합했을 때에는 2 두에서만 동일 유전자형 조합을 나타내었다. MS와 모색유전자 분석자료를 모두 조합했을 때는 조사된 모든 개체들이 서로 구분 되었다. 현재의 제주흑우집단이 소수 핵군에서 인공수정과 수정란이식 등 생명공학 기법으로 육성된 집단이기에 제주흑우집단의 유전적 다양성은 낮게 나타났다. 본 연구는 유전자 개체식별과 혈통관리 체계의 구축을 위해서 는 적어도 20개 이상의 MS marker와 모색관련 유전자형 자료가 필수적으로 활용되어야함을 제안하고 있으며, 연구결과는 향후 제주흑우의 분자육종에 있어 유용한 자료가 될 것으로 시사하고 있다. 